\title{
Csilla CsÁK* \\ Integrated agricultural organisation of production system and the organisations carrying that ${ }^{* *}$
}

Different levels and forms of integration structure developed within agriculture. Integrated systems are classified in different ways in the literature as well, several approaches are possible. Integration - which is the organised form of cooperation - can be achieved through a contractual relationship or by establishing common organisational frameworks but in both cases we can talk about a coordinated action. Integration relations established within the framework of organisational cooperation can be horizontal or vertical. In the model of horizontal integration usually the collaboration of companies with the same economic potential can be observed. ${ }^{1}$ The participants of the collaboration cooperate with each other in order to exploit and increase their economic strength. Vertical integration means the integration of a product sector, as it basically relates to a product sector. In the case of contractual integration the similar types occur with the difference that this model is not an organisational unity in company law sense but it is an activity-oriented regulatory unity. ${ }^{2}$

Csilla Csák: Integrated agricultural organisation of production system and the organisations carrying that - Integrált mezőgazdasági termelésszervezés illetve az azt végző szervezetek. Journal of Agricultural and Environmental Law ISSN 1788-6171, 2018 Vol. XIII No. 25 pp. 6-21 doi: 10.21029/JAEL.2018.25.6

* dr. jur., PhD, dr. habil., full professor, University of Miskolc, Faculty of Law, Department of Agricultural and Labour Law, e-mail: jogkincs@uni-miskolc.hu

** This study has been written as part of the Ministry of Justice programme aiming to raise the standard of law education.

${ }^{1}$ Szilágyi János Ede: A magyar víziközmú-szolgáltatók integrációja jogi nézőpontból, Pro Futuro, 2014/1, 144-162; Olajos István: Földgázpiac és szabályozása, in: Szilágyi János Ede (ed.): Környezetjog II: Tanulmányok a környezetjogi gondolkodás köréböl, Miskolc, Novotni Alapitvány, 175194; Réti Mária: Az integráció, in: Vass János (ed.): Agrárjog, Budapest, ELTE Állam- és Jogtudományi Kar, 1999, 194-200; Bándi Gyula: Környezetvédelem, fenntartható fejlődés és integráció, in: Halustyik Anna - Klicsu László (ed.): Cooperatrici veritatis: Ünnepi kötet Tersztyánszkeyné Vasadi Éva 80. születésnapja alkalmából, Budapest, Pázmány Press, PPKE JÁK, 2015, 49-70; Bándi Gyula: Environmental aspects of EC Law approximation, in: Inotai András - Vida Krisztina (ed.): Financial transfers of the European Union and Eastern enlargement: Proceedings of the joint international conference of Trans European Policy Studies Association, Institute for World Economics, Strategic Task Force for European Integration, 138; Fodor László: Integration und Umweltschutzrecht in Ungarn, in: Ващук $Ф$ Г, ПереАрій О С, Олексик X M, Ухаль А М, Крижанівскій В П, Молдован В В, Павлов О А (ed.): Theory and practice of market transition period: economic, law and international aspects, Konferencia helye, ideje: Szlovákia, 2001.03.27-2001.03.30, Ungvár, 54-59; Fodor László: Integrativitás és integráció, avagy újabb kihívások hazai környezetjogunkkal szemben, Magyar Jog, 1999/7, 398-409.

2 Szilágyi János Ede: Az európai integrációt megelőző magyar borjog története, Publicationes Universitatis Miskolciensis series Juridica et Politica, 20008/1, 197-225; Szilágyi János Ede: A bor 
The importance and significance of integrated relations are determined by their state recognition. Integration is an indispensable element and precondition of agricultural organisation of production. Various integration models have developed concerning historical perspective and they have a growing importance. In itself multifunctional agriculture $^{3}$ is an integration model, such kind of integration model that realizes the integration of different interests, such as economic, social and environmental protection interests. There are mandatory elements, rules of the validation of different interests, e.g. cross compliance, etc., when agri-environmental or environmental interests shall be taken into consideration and shall be combined in economic activities.

In addition, there are such common interests that appear as possible elements, such as promotion and validation of social character within the frame of agricultural activity. In the long term, the development and placement of possible interests integration into agricultural frames creates the real purpose of integration in which case the complex treatment of economic and social issues may be carried out.

In this study I would like to illustrate the organizational and contractual form of economic integration, the realization forms and further development possibilities of interest integration from legal regulation point of view. In itself, integration is a quite broad term which is considered to be an organised, state-recognised form in order to enforce economic or economic and individual interests and benefits.

\section{Organisational issues of economic integration}

Several theories have developed for the economic theoretical approach and analysis of agro-economic activities and cooperative relations and for the examination of paradigms and alternative paradigms from economics perspective. Economic utility, expediency analysis and models have been defined which can be regarded as decisive

közös piacszervezetének kialakulása és fejlődése, valamint a magyar integráció, Studia Iurisprudentiae Doctorandorum Miskolciensium-Miskolci Doktoranduszok Jogtudományi Tanulmányai, 2008/9, 447-466; Andréka Tamás - Bányai Krisztina - Olajos István: A magyar agrár-piacpolitika legfontosabb változásai a Közös Agrárpolitika 2013-as reformját követően, Agrár-és Környezetjog, 2015/19, 19-32; Olajos István: A telepítési jogok helye és szerepe a borpiaci rendtartásban, in: Cserba Lajos (ed.): A magyar bor, mint a jogvédelem tárgya, conference, Miskolc, Hungary, 11.11.2011, 1-15; Kurucz Mihály: Közjogi korlátozások a piacszabályozás körében, in: Vass János (ed.): Agrárjog, Budapest, ELTE ÂJK, 1999, 235-271; Bándi Gyula: Integrated water policy as a part of the EU enlargement process: the case of Hungary, in: Thomas Bruha - Hans-Joachim Koch (ed.): Integrierte Gewässerpolitika in Europa: Gewässerschutz, Wassernutzung, Lebensraumschutz, Baden-Baden, Nomos, 2001, 297-316.

${ }^{3}$ Fodor László: A multifunkcionális és fenntartható mezőgazdaság európai modellje, Pro Futuro A Jövö Nemzedékelk Joga, 2012/2, 128-137; Olajos István: A fenntartható földhasználat határai, avagy dilemmák az energetikai növények termeszthetőségének kérdésében, in: Csák Csilla (ed.): Jogtudományi tanulmányok a fenntartható természeti eróforrások témakörében, Miskolc, University of Miskolc, 2012, 142-151; Bándi Gyula: A fenntarthatóságtól a körkörös gazdaság felé: EU stratégiák alakulása és ennek jogi következményei, Fontes Iuris: Az Igazságügyi Minisztérium Szakmai Folyóirata, 2016/1, 13-21. 
elements from economic policy point of view. However, economic integration must fit into the systematic system of organisation of production and management which organisational frameworks and operating mechanisms are ensured by legal regulation.

In historical approach, the cooperative sector belongs to this organisational system which is explicitly classified into integrative organisations today but considering its history cooperatives realized a high level of cooperation examining their specific features. ${ }^{4}$ Although, there was a different regulatory direction before and after the change of regime and there is in the current operational model. The different approach of this model appears in particular in the relation between the cooperative and its members. Before the change of regime -in the system of common use systemmembership interests were subordinated to the cooperative, then the balance of interests and the promotion of membership interests appeared in the legislation of cooperatives (1992, 2000, 2006, 2013) (in agricultural level but in generally as well) according to the role of cooperatives that "co-operative is a legal person with the objective to satisfy the members economic and social needs...". ${ }^{5}$ This provision clearly defines those features of cooperatives that serve the interests of the members and the purchasing, sale, service, etc. activities of cooperatives. The organisational framework of cross-border cooperation appears in cooperative level as well by introducing the regulation of European Cooperative Society (SCE) into the EU legislation ${ }^{6}$ and Member State's legislation ${ }^{7}$. SCE, considering its legal nature, is a supranational legal person founded with subscribed share capital and variable capital that carries on the cooperative principles and values. The principal objects of European Cooperative Society should have the satisfaction of its members' needs and/or the development of their economic and/or social activities, in compliance with the following principles which principles reflect the international co-operative principles as well and takes on them: (a) fits activities should be conducted for the mutual benefit of the members so that each member benefits from the activities of the SCE in accordance with his/her

\footnotetext{
${ }^{4}$ Károly Ihrig classified cooperatives into two big category: supply and demand cooperatives. Both common feature that they intend to promote the producer interests of members but they implement this aim in different ways and with different tools. Supply cooperatives intended to increase profit by the placement of products with favourable conditions - higher volume, higher price. Demand cooperatives: (a) cooperative Banks: reduced production costs and provided higher profit on the same prices through favourable loans; (b) purchasing cooperatives: reduced production costs and provided higher profit by insuring materials and tools on a favourable price; (c) machine use cooperative: reduced production costs and provided higher profit by insuring means of production; (d) land lease cooperatives: reduced production costs and provided higher profit by acquiring agricultural land. See more: Ihrig Károly: A sqövetkezetek a közgazdaságban, Budapest, Első Kecskeméti Nyomda és Hírlapkiadó Rt, 1937, 119.

${ }^{5}$ Act V of 2013 on the Civil Code $\ 3: 325$ (1).

${ }^{6}$ Council Regulation (EC) No 1435/2003 on the Statute for a European Cooperative Society (SCE) (the Regulation came into force on 18 August 2006) and Council Directive 2003/72/EC supplementing the Statute for a European Cooperative Society with regard to the involvement of employees (the Directive came into force on 18 August 2003 and Member States had to implement it into the national legislation until 18 August 2006).

${ }^{7}$ Act LXIX of 2006 on European Cooperative Society.
} 
participation (the priority of membership interests); (b) members of the SCE should also be customers, employees or suppliers or should be otherwise involved in the activities of the SCE (personal capacity); (c) control should be vested equally in members, although weighted voting may be allowed, in order to reflect each member's contribution to the SCE (democratic administration, the principle of one member has one vote); (d) there should be limited interest on loan and share capital (limited capital interest); (e) profits should be distributed according to business done with the SCE or retained to meet the needs of members (profit allocation based on participation, solidarity); (f) there should be no artificial restrictions on membership (open membership); (g) net assets and reserves should be distributed on winding-up according to the principle of disinterested distribution, that is to say to another cooperative body pursuing similar aims or general interest purposes (joint responsibility). ${ }^{8}$

As the result of the harmonised regulation of EU legislation and Hungarian legislation appeared the producer organisations and producer groups. EU legislation on producer organisations is the Regulation (EU) No 1308/20139 which established a common organisation of the markets of agricultural products. Member States may -on request- recognise producer organisations, which: (a) are constituted, and controlled by producers in a specific sector listed in the Regulation; (b) are formed on the initiative of the producers; (c) pursue a specific aim which may include at least one of the following objectives: (ci) ensuring that production is planned and adjusted to demand, particularly in terms of quality and quantity; (cii) concentration of supply and the placing on the market of the products produced by its members, including through direct marketing; (ciii) optimising production costs and returns on investments in response to environmental and animal welfare standards, and stabilising producer prices; (civ) carrying out research and developing initiatives on sustainable production methods, innovative practices, economic competitiveness and market developments; (cv) promoting, and providing technical assistance for, the use of environmentally sound cultivation practices and production techniques, and sound animal welfare practices and techniques; (cvi) promoting, and providing technical assistance for, the use of production standards, improving product quality and developing products with a protected designation of origin, with a protected geographical indication or covered by a national quality label; (cvii) management of by-products and of waste in particular to protect the quality of water, soil and landscape and preserving or encouraging biodiversity;(cviii) contributing to a sustainable use of natural resources and to climate change mitigation; (cix) developing initiatives in the area of promotion and marketing; etc.

A producer group or a producer organisation gains its status as the result of state recognition which decision is taken by the Minister for Agricultural Policy.

${ }^{8}$ Council Regulation (EC) No 1435/2003 on the Statute for a European Cooperative Society, Introductory Provisions.

${ }^{9}$ Regulation (EU) No 1308/2013 of the European Parliament and of the Council (17 December 2013) of establishing a common organisation of the markets in agricultural products and repealing Council Regulations (EEC) No 922/72, (EEC) No 234/79, (EC) No 1037/2001 and (EC) No $1234 / 2007$. 
Organisations, operating in cooperative form or in certain cases in business association form, may apply successfully for state recognition under certain conditions and in the case of enforcement of operational mechanism required by legal regulation. Producers operating according to the same product or group of products, concentrated into integrator organisation achieve a higher integration level by state recognition. A (agricultural) cooperative or a business association recognised as a producer group or a producer organisation supplies services for its members and carries out activities in order to strengthen the member's market position. A close and coordinated relationship and operational order between members and the organisation is required by legal regulation which means that the members and the organisation shall conclude a purchasing agreement, they shall observe strict production rules, a specific amount of their production of goods shall be distributed through the organisation and they may sell only their own produced products to the members of the group. Provisions on the operational order of producer groups and producer organisations and the compliance of them are closely linked to the Common Agricultural Policy (CAP) and to the expectations of the CAP-associated support aims and procedure.

\section{The forms of economic integration based on cooperation contract}

Within the organisations which are recognised as a producer organisation or a producer group it is compulsory to be a contractual relationship between the members and the integrator organisation in order to ensure economic activities. However, we have to distinguish the integration cooperation agreement within the organisation from the cooperative relations and contractual relations of persons who exercise agricultural activities as independent legal entities. These contractual relationships may be various, such as, a contract concluded between agricultural operators. Another type is a contractual relationship between the moderator and a person exercising agricultural activity, when the moderator supplies services for the external (non member) integrated person. Integrated contractual relationship can be distinguish according to the degree, magnitude (contracted sales volume, etc.) or the extent (number of integrated people) of integration. Pursuant to this classification we can talk about local, regional and national relationship forms. Contractual relationship may be established for products, group of products or product sector.

The Civil Code creates the legal regulation of contractual relationship. The Civil Code regulates typical contracts within the frame of the sales contracts for the supply of own produced agricultural goods ${ }^{10}$ and sales contracts for the supply of

${ }^{10}$ 6:232 [Sales contracts for the supply of own produced agricultural goods]

(1) If the seller undertakes an obligation for the supply of agricultural goods and/or produce of his own production or livestock that he himself has raised at a future date, he shall be entitled to perform ten per cent below the quantity stipulated in the contract.

(2) The seller shall also be entitled to effect performance of the contract referred to in Subsection (1) before the stipulated delivery date, provided that the buyer is notified in advance of commencement of performance while ample time is provided to him to make the necessary preparations. 
agricultural goods produced with the buyer's involvement. ${ }^{11}$ The National Chamber of Agriculture drew up a proposal about developing the contractual construction of integrated organisation of product according to the product sector. The proposal would regulate the integration contract as a sui generis contract which legislative background is the Civil Code, exactly the provisions of sales contracts which are concluded for agricultural goods produced with the assistance of the buyer and integration contract combines the contractual rules of producer organisations. Regarding the subjects of this contract, state recognition and the registration process of an integrating organisation is an essential condition in the integration construction as well. Besides the elements of services and economic relationships the benefits and advantages associated to the model are essential and progressive: (a) machine service provided on the basis of organisation of production (integration) contract by the production manager (integrator) for integrated enterprise in favour of producing crops and productions, harvesting products, livestock production and their transportation and processing shall be considered as his/her own activities according to authorisation; (b) products and crops production, breeding and keeping animals, transportation of them carried on by the integrator for the integrated enterprise shall be considered as the transportation carried on by himself; (c) the integrator who carries on regional or national organisation of production can provide financial service for the enterprise integrated by him/her without the permission of the Hungarian National Bank; (d) certain investments, exceeding at least one billion Forint which is implemented by an enterprise carrying on national organisation of production, shall be considered as economically priority investments; (e) the sale of goods by the production manager (integrator) within the frame of organisation of production (integration) contract is not considered as wholesale activity; (f) profit before taxes should be reducible by the recognised production manager (integrator) in the amount of $3 \%$ of net income of product (purchased under organisation of production (integration) contract) which is placed in a separate mutual funds purchased, and the profit shall be used for the payments of market risks relating to organisation of production services and for research and development payments.

The substantial part of benefits prejudices the reduction of tax and financial burden which improve the conditions of operation. The recognition and legalisation of the function of integrator financial service is a very exciting issue. One of the factors and perhaps the most important factor is the resource and financial stability for agricultural operators. The service formulated in the proposal may help in the solutions

11 6:233 [Sales contracts for the supply of agricultural goods produced with the buyer's involvement]

If the seller undertakes an obligation for the supply of agricultural goods and/or produce of his own production or livestock that he himself has raised at a future date, and based on the parties' agreement the buyer is required to provide assistance to facilitate performance, and to provide information to the seller in that context, the seller shall cooperate in the provision of such service by following the instructions communicated. The seller shall pay the contracted price for the buyer's service provided to facilitate performance, and shall repay the part of any production advance received from the buyer that is not covered by the purchase price even if the production result is insufficient to cover such payments. 
of it which may improve the operating conditions of resources, financial service and sales. Considering the historical background when Raiffeisen financial cooperatives (the second part of the XIX century) served these tasks towards the German rural people. The basic activities of these Raiffeisen-type cooperatives went beyond the collection of deposit and lending because they became the indicator of village life by promoting production. This aim determined the assets in which occurred the lending activity, purchasing, sales activity and other community services too. ${ }^{12}$

\section{The integration of interests in the framework of agriculture}

The idea of sustainable development, the model of multifunctional agriculture or the integration of external and internal EU policies justify that in many cases the elements of the realization of the objectives show a complex relationship between the levels and types of cooperation. However, it is common in them that in certain activity areas specific resources are mobilised and linked.

New forms of employment based on agricultural activities appear, such as the social farm model. In the model of social farm different forms of social and economic cooperation appear. The directions of interaction, cooperation are: (a) social responsibility, joint responsibility; (b) sustainable agriculture; (c) environmental awareness; (d) personal development (skills and capability development); (e) transfer of knowledge; (f) economic advantages (production, processing, sales, utilisation, income).

In accordance with social and solidarity principles, social farm is a cooperative economic form in the interest of social and environmental awareness, which performs agricultural productive, processing and service activities with the involvement of underprivileged people; and it performs additional awareness shaping activities related to agriculture for wider society. Regarding the agricultural operators, income resulting from agricultural activities is decisive. Small, medium and large plants belong to the operators. There is no form requirements for the operators who carrying on agricultural activities, so these activities may be carried on in any organisational forms (business association, co-operative, private entrepreneur, small-scale agricultural producer, family farm. etc.). Support and tax system is a largely decisive factor in choosing the form of the operator. Agricultural activity is closely linked to the use of agricultural lands. However, it should be mentioned that only a specific group of persons has right to land use and land ownership according to the law. This limitative condition can not be ignored.

The Common Agricultural Policy had to respond to the issue of sustainability with regard to the past decades and present challenges and emphasis was placed on multifunctional approach of agriculture and on the diversification of public goods and farms - including the improvement of the quality of life in rural areas. This is the question and the answer raises the extension of the concept of agricultural (basic) activities, secondary activity and the activities outside them in respect of on-farm and off-farm activities as well. This process - contrary to specialisation - leads to the multifunctional approach through diversification.

12 Bátori Lóránt: A Raiffeisen-i szövetkezeti mozgalomról, Szövetkezés, 1997/1-2, 129-139. 


\section{Closing thoughts}

Constructions and the legal regulation of agricultural organisation of production can be found in the legislation of the previous period and we can find legal institutions referring to it and specially developed solutions in the current legislation as well. The relationship forms of agricultural organisation of production may be closer or looser in the sense that the establishment of organisational unity (according to company law sense) is not required in the contractual relationship of integration, so the content of regulation is activity-oriented. However, it can be said that according to public law and private law provisions only a part of regulation is dispositive (derogating rules), mainly the cogent (mandatory) regulatory methodology prevails within integration. It is a key issue to incorporate the elements of the integrated model, to clarify the role of different integrator constellations and to determine their interfaces. Furthermore, it shall be taken into account that Fundamental Law also contains authorisation for the establishment of legislation for integrated organisation of production. 


\section{CSÁK Csilla*}

\section{Integrált mezőgazdasági termelésszervezés illetve az azt végző szervezetek**}

Az agráriumban az integráció különböző szintű és formájú struktúrái alakultak ki. Az integrált rendszereket a szakirodalom is különböző módon csoportosítja, több megközelítés is lehetséges. Az integráció - amely az együttmúködés szervezett formája - megvalósulhat szerződéses kapcsolaton keresztül, illetőleg közös szervezeti keretek létrehozásával egyaránt, de mindkét esetben valamely tevékenység összehangolt folytatásáról beszélhetünk. A szervezeti együttműködés keretei között létrejövő integrációs kapcsolatok azokat a kapcsolatokat jelenti, amelyek horizontális vagy vertikális irányú lehetnek. A horizontális integrációs modellben általában azonos gazdasági potenciállal rendelkező vállalkozások összefogása ${ }^{1}$ figyelhető meg, amely résztvevők gazdasági erejük kihasználása és növelése érdekében fognak össze. A vertikális integráció termékpálya integrációt jelent, alapvetően a termékpályához kapcsolódik. ${ }^{2}$ A szerződéses integráció esetében is hasonló típusokról beszélhetünk,

Csilla Csák: Integrated agricultural organisation of production system and the organisations carrying that - Integrált mezőgazdasági termelésszervezés illetve az azt végző szervezetek. Journal of Agricultural and Environmental Law ISSN 1788-6171, 2018 Vol. XIII No. 25 pp. 6-21 doi: 10.21029/JAEL.2018.25.6

* dr. jur., PhD, dr. habil., egyetemi tanár, Miskolci Egyetem Állam- és Jogtudományi Kar, Agrárés Munkajogi Tanszék, e-mail: jogkincs@uni-miskolc.hu

** A tanulmány az Igazságügyi Minisztérium jogászképzés szinvonalának emelését célzó programjai keretében valósult meg.

${ }^{1}$ Szilágyi János Ede: A magyar víziközmű-szolgáltatók integrációja jogi nézőpontból, Pro Futuro, 2014/1, 144-162.; Olajos István: Földgázpiac és szabályozása, in: Szilágyi János Ede (szerk.): Környezetjog II.: Tanulmányok a környezetjogi gondolkodás köréböl, Miskolc, Novotni Alapítvány, 2010, 175-194.; Réti Mária: Az integráció, in: Vass János (szerk.): Agrárjog, Budapest, ELTE Állam- és Jogtudományi Kar, 1999, 306, 194-200.; Bándi Gyula: Környezetvédelem, fenntartható fejlődés és integráció, in: Halustyik Anna - Klicsu László (szerk.): Cooperatrici veritatis: Ünnepi kötet Tersztyánszkeyné Vasadi Éva 80. születésnapja alkalmából, Budapest, Pázmány Press, PPKE JÁK, 2015, 49-70.; Bándi Gyula: Environmental aspects of EC Law approximation, in: Inotai András - Vida Krisztina (szerk.): Financial transfers of the European Union and Eastern enlargement: Proceedings of the joint international conference of Trans European Policy Studies Association, Institute for World Economics, Strategic Task Force for European Integration, 138.; Fodor László: Integration und Umweltschutzrecht in Ungarn, in: Ващук Ф Г, ПереАрій О С, Олексик X M, Ухаль А М, Крижанівскій В П, Молдован В В, Павлов О А (szerk.): Theory and practice of market transition period: economic, law and international aspects, Konferencia helye, ideje: Szlovákia, 2001.03.27-2001.03.30, Ungvár, 54-59.; Fodor László: Integrativitás és integráció, avagy újabb kihívások hazai környezetjogunkkal szemben, Magyar Jog 1999/7, 398-409.

2 Szilágyi János Ede: Az európai integrációt megelőző magyar borjog története, Publicationes Universitatis Miskolciensis series Juridica et Politica, 2008/1, 197-225.; Szilágyi János Ede: A bor közös piacszervezetének kialakulása és fejlődése, valamint a magyar integráció, Studia Iurisprudentiae Doctorandorum Miskolciensium-Miskolci Doktoranduszok Jogtudományi 


\section{Csák Csilla \\ Integrált mezőgazdasági termelésszervezés \\ illetve az azt végző szervezetek}

Agrár- és Környezetjog

2018. 25. szám

azzal az eltéréssel, hogy ebben az esetben cégjogi értelemben vett szervezeti egységről nem, hanem tevékenység orientált szabályozási egységről van szó. Az integrációs kapcsolatok súlyát és jelentőségét meghatározza annak állami elismertsége. Az integráció a mezőgazdasági termelésszervezés elengedhetetlen eleme és létfeltétele. Különbözô mélységű integrációs modellek alakultak ki a történelmei távlatokat tekintve is és napjainkban is egyre nagyobb a jelentősége. Önmagában véve a multifunkcionális mezőgazdaság ${ }^{3}$ is integrációs modellt jelent, olyan jellegű integrációt, amely különböző érdekek integrálását valósítja meg, mint pl. a gazdasági, a szociális, a környezetvédelmi. A különböző érdekek érvényesítésének vannak kötelező elemei, előírásai, mint például a cross complience esetében, amikor agrár-környezetvédelmi illetőleg környezetvédelmi érdekeket is figyelembe kell venni, ötvözni kell a gazdasági tevékenység végzése során.

Mindezek mellett természetesen vannak olyan érdekösszhangok is, amelyek lehetséges elemként jelennek meg, mint pl. a társadalmi jelleg előtérbe helyezése és érvényesítése a mezőgazdasági tevékenység keretei között. Hosszú távon ennek a lehetséges érdekintegrációnak a megteremtése és mezőgazdasági keretek közé helyezése jelenti az integráció valódi célját, amely esetben gazdasági és társadalmi kérdések komplex kezelésére kerülhet sor.

Jelen tanulmány kereti között néhány példával kívánom illusztrálni a gazdasági integráció szervezeti, a szerződéses útjait, illetőleg az érdekintegrációnak a megvalósulási formáit és továbbfejlesztési lehetőségeit a jogi szabályozás szemszögéből. Az integráció önmagában véve egy meglehetősen tág fogalom, amelyet a kooperáció szervezett, állam által elismert formájának tekintünk, a gazdasági illetőleg a gazdasági és egyén érdekek és előnyök érvényre juttatása érdekében.

\section{A gazdasági integráció szervezeti kérdései}

Az agrárgazdasági tevékenység végzésének és kooperációs kapcsolatainak gazdaság-elméleti megközelítésére és elemzésére, paradigmák és alternatív paradigmák

\footnotetext{
Tanulmányai, 2008/9, 447-466.; Andréka Tamás - Bányai Krisztina - Olajos István: A magyar agrár-piacpolitika legfontosabb változásai a Közös Agrárpolitika 2013-as reformját követően, Agrár-és Környezetjog, 2015/19, 19-32.; Olajos István: A telepítési jogok helye és szerepe a borpiaci rendtartásban, in: Cserba Lajos (szerk.): A magyar bor, mint a jogvédelem tárgya, Konferencia helye, ideje: Miskolc, Magyarország, 2011.11.11, 1-15.; Kurucz Mihály: Közjogi korlátozások a piacszabályozás körében, in: Vass János (szerk.): Agrárjog, Budapest, ELTE Állam- és Jogtudományi Kar, 1999, 235-271.; Bándi Gyula: Integrated water policy as a part of the EU enlargement process: the case of Hungary, in: Thomas Bruha - Hans-Joachim Koch (szerk.): Integrierte Gewässerpolitika in Europa: Gewässerschutz, Wassernutzung, Lebensraumschut\%, Baden-Baden, Nomos, 2001, 297-316.

${ }^{3}$ Fodor László: A multifunkcionális és fenntartható mezőgazdaság európai modellje, Pro Futuro A Jövő Nemzedékeke Joga, 2012/2, 128-137.; Olajos István: A fenntartható földhasználat határai, avagy dilemmák az energetikai növények termeszthetőségének kérdésében, in: Csák Csilla (szerk.): Jogtudományi tanulmányok a fenntartható természeti eröforrások témakörében, Miskolc, Miskolci Egyetem, 2012, 142-151.; Bándi Gyula: A fenntarthatóságtól a körkörös gazdaság felé: EU stratégiák alakulása és ennek jogi következményei, Fontes Iuris, Az Igazságügyi Minisztérium Szakmai Folyóirata, 2016/1, 13-21.
} 


\section{Csák Csilla \\ Integrált mezőgazdasági termelésszervezés \\ illetve az azt végző szervezetek}

Agrár- és Környezetjog

2018. 25. szám

közgazdasági szempontú vizsgálatára számos elmélet született. A gazdasági hasznosság, célszerűségi méretelemzések és modellek meghatározására került sor, amely gazdaságpolitikai szempontból meghatározó szempontnak tekinthetô. A gazdasági integrációnak ugyanakkor a termelésszervezés és irányítás szisztematikus rendszerébe is illeszkednie kell, amelynek szervezeti kereteit és múködési mechanizmusait a jogi szabályozottság biztosítja.

Történeti megközelítésben ebbe a szervezet rendszerbe illeszkedik a jól ismert szövetkezeti szektor, amelyet ma egyértelműen az integratív szervezetek közé sorolunk, de történetiségében a meghatározó jegyeinek vizsgálata során is a kooperáció magas fokát valósította meg. ${ }^{4}$ Bár kétségtelenül eltérő szabályozottsági iránnyal a rendszerváltás előtti, utáni és a jelenlegi működési modellt tekintve. A modell eltérô megközelítése különösen a szövetkezet és a tagság kapcsolatrendszerében követhető nyomon. A rendszerváltás előtt - a közös használat rendszerében - a tagsági érdekek a szövetkezetnek alárendelten jelentek, majd ezt követően a szövetkezeteket érintő jogi szabályozásban nyomon követhető (1992, 2000, 2006, 2013) az érdekek egyensúlyba hozása, majd a tagsági érdekek előtérbe helyezése, az (agrárgazdasági szinten is, de általában is a) szövetkezeteknek azon szerepéből levezetve, mely szerint „a szövetkezęt ... a tagok gazdasági és társadalmi szülkségleteinek kielégitésére irányuló tevékenységet végzó jogi személy...”. ${ }^{5}$ Ez egyértelműen meghatározza a szövetkezetek azon jellemzőjét, amely a tagság érdekeinek kiszolgálására, a szövetkezetek beszerző, értékesítő, szolgáltató stb. jellegének meghatározására irányul. Szövetkezeti szinten is ugyanakkor megjelenik a határon átnyúló együttmúködések szervezeti kereteinek a meghatározása, az európai szövetkezet (SCE) uniós joganyagba ${ }^{6}$ illesztésével és a tagállami joganyagokban ${ }^{7}$ való megjelenésével. Az SCE jogi jellegét tekintve meghatározott jegyzett tókével alapított, változó tőkéjü szupranacionális jogi személy, amely magán hordozza a szövetkezeti elveket és értékeket. Az SCE alapvető célja tagjai szükségleteinek kielégítése és/vagy

${ }^{4}$ Ihrig Károly a vállalkozók szövetkezeteit két nagy csoportba sorolta: kínálati és keresleti szövetkezetek elnevezéssel. Mindkettő közös jellemzője, hogy a tagok termelői (vállalkozói) érdekeit kívánja elősegíteni, de ezt különböző módon és eszközökkel valósítja meg. A kínálati szövetkezetek, az ún. áruelhelyező-szövetkezetek, amelyek a termelt áru, termény kedvezőbb feltételekkel - nagyobb volumenben, magasabb áron - való elhelyezésével kívánták növelni a nyereséget. A keresleti szövetkezetek: (a) hitelszövetkezetek: kedvező kölcsön biztosításán keresztül a termelési költség csökkentésével, azonos piaci ár mellett nagyobb nyereséget biztosítva (b) beszerző szövetkezetek: felhasznált anyagok, eszközök kedvező áron történő biztosítása (c) géphasználó szövetkezetek: termelőeszközöket biztosít a termeléshez (d) földbérlő szövetkezetek: mezőgazdaságilag használt föld előnyös megszerzésével érték el a termelési költség - csökkentést és ezáltal a nagyobb nyereséget. Lásd bővebben: Ihrig Károly: $A$ szövetkęretek a kö̈ggazdaságban, Budapest, Első Kecskeméti Nyomda és Hírlapkiadó Rt., 1937, 119. 5 2013. évi V. törvény 3:325. \(1) bekezdés.

6 1435/2003/EK rendelet az európai szövetkezet (SCE) statútumáról (a rendelet 2006. augusztus 18-án lépett hatályba), valamint a 2003/72/EK irányelv az európai szövetkezet statútumának a munkavállalói részvétel tekintetében történő kiegészítéséről (az irányelv 2003. augusztus 18-án lépett hatályba és 2006. augusztus 18-ig kellett átültetni a nemzeti jogba a tagállamoknak).

7 2006. évi LXIX. törvény az európai szövetkezetről. 


\section{Csák Csilla \\ Integrált mezőgazdasági termelésszervezés \\ illetve az azt végző szervezetek}

Agrár- és Környezetjog

2018. 25. szám

azok gazdasági és/vagy szociális tevékenységeinek fejlesztése a következő alapelvekkel összhangban, amely alapelvek a nemzetközi szövetkezeti elveket egyaránt tükrözik, azokat átveszik: (a) tevékenységeinek a tagok kölcsönös javát kell szolgálnia oly módon, hogy valamennyi tag saját részvételének megfelelően részesüljön az SCE tevékenységeiből (tagsági érdekek prioritása); (b) az SCE tagjainak egyúttal fogyasztóknak, alkalmazottaknak vagy szállítóknak is kell lenniük, illetve más módon kell részt venniük az SCE tevékenységében (személyes közremúködés); (c) az ellenőrzés a tagokat egyenlő mértékben illeti meg, megengedett azonban a súlyozott szavazás az egyes tagoknak az SCE tevékenységéhez való hozzájárulásának tükröződése érdekében (demokratikus igazgatás, egy tag egy szavazat elvének fő szabálya); (d) korlátozni kell a kölcsön és az üzletrésztőke kamatának mértékét (korlátozott tôkekamat); (e) a nyereséget az SCE érdekében végzett üzleti tevékenységnek megfelelően kell felosztani, vagy vissza kell tartani a tagok szükségleteinek kielégítése céljából (részvétel alapján történő nyereség felosztás, szolidaritás); (f) a tagság mesterségesen nem korlátozható (nyitott tagság); (g) felszámolás esetén a nettó vagyont és a tartalékokat a pártatlan felosztás elve szerint kell felosztani, ami azt jelenti, hogy egy másik olyan szövetkezeti szervezetnek kell juttatni azokat, amely hasonló célok érdekében jött létre, vagy hasonló általános érdekeket szolgál (közös felelősség). ${ }^{8}$

Az uniós joganyag és a hazai joganyag harmonizált szabályozásának eredményeként megjelentek a termelői szervezetek illetőleg termelői csoportok. A termelői szervezetekkel kapcsolatos uniós rendeleti joganyag, a 1308/2013/EU rendelet, ${ }^{9}$ amely létrehozta az egyes mezőgazdasági termékek piacának közös szervezését. A rendelet alapján a tagállamok - kérelem alapján - elismerhetik azokat a termelői szervezeteket, amelyek: (a) a rendelet által meghatározott valamely ágazatban múködő termelőkből állnak, és e termelőknek demokratikus ellenőrzése alatt állnak; (b) a termelők kezdeményezésére jöttek létre; (c) meghatározott célokkal múködnek, amelyek legalább egyike az alábbiakra vonatkozhat: (ci) a termelés megtervezésének és a kereslethez való hozzáigazításának biztosítása, különösen a minőség és a mennyiség tekintetében, (cii) a kínálati oldal koncentrációja és a tagok által előállított termékek forgalomba hozatala, többek között közvetlen üzletszerzés révén; (ciii) a termelési költségeknek és a környezetvédelmi és állatjóléti előírások teljesítése céljából végrehajtott beruházások megtérülésének optimalizálása és a termelői árak stabilizálása, (civ) kutatások folytatása és kezdeményezések kidolgozása a fenntartható termelési módszerekkel, innovatív gyakorlatokkal, a gazdasági versenyképességgel és a piac alakulásával kapcsolatban; (cv) a környezetkímélő termesztési gyakorlatok és termelési technikák, illetve megfelelő állatjóléti gyakorlatok és technikák használatának előmozdítása, valamint technikai segítségnyújtás az ilyen gyakorlatok és technikák alkalmazásához; (cvi) a termelési szabványok használatának előmozdítása és az ehhez biztosított technikai segítségnyújtás, a termékminőség javítása, valamint oltalom alatt

\footnotetext{
8 1435/2003/EK rendelet az európai szövetkezet (SCE) statútumáról, Preambulum.

9 Az Európai Parlmanet és a Tanács 1308/2013/EU Rendelete (2013. december 17.) a mezőgazdasági termékpiacok közös szervezésének létrehozásáról és a 922/72/EGK, a 234/79/EGK, az 1037/2001/EK és az 1234/2007/EK tanácsi rendelet hatályon kívül helyezéséről.
} 
Csák Csilla

Integrált mezőgazdasági termelésszervezés

illetve az azt végző szervezetek
Agrár- és Környezetjog

2018. 25. szám

álló eredetmegjelöléssel, oltalom alatt álló földrajzi jelzéssel vagy nemzeti minőségigazoló címkével ellátott termékek fejlesztése; (cvii) a melléktermékek és a hulladékok kezelése, különösen a víz, a talaj és a táj minőségvédelme tekintetében, valamint a biológiai sokféleség megőrzése vagy előmozdítása; (cviii) hozzájárulás a természeti erőforrásokkal való fenntartható gazdálkodáshoz és az éghajlatváltozás mérsékléséhez; ix. kezdeményezések kidolgozása a promóció és a forgalmazás terén stb.

A termelői csoport illetôleg termelői szervezet állami elismerés eredményeként nyeri el státuszát, amely döntés meghozatalára az agrárpolitikáért felelős miniszter jogosult. Szövetkezeti formában illetőleg meghatározott esetekben gazdasági társasági formában múködő szervezetek bizonyos feltételek fennállása esetén és a jogi szabályozás által megkívánt múködési mechanizmusok érvényesítése esetén pályázhatnak sikeresen az elismerésre. Az azonos termék vagy termékcsoport szerint szerveződő, integrátori szervezetbe tömörült termelők magasabb integrációs szintre lépnek az állami elismerés által. A termelői csoportként vagy termelői szervezetként elismert (agrárgazdasági) szövetkezet vagy gazdasági társaság a tagjai számára szolgáltatásokat nyújt és meghatározott tevékenységeket folytat a tagok piaci pozícióinak erősítése érdekében. A tagok és a szervezet között szoros és összehangolt kapcsolat és múködési rend kialakítását követeli meg a jogi szabályozás, amely azt jelenti, hogy a tag és a szervezet között értékesítési szerződést kell kötni, szigorú termelési szabályokat be kell tartani, valamint az elismerés tárgyát képező árutermelésük meghatározott mértékét a termelői csoporton, szervezeten keresztül forgalmazzák, és csak saját maguk által megtermelt vagy előállított terméküket értékesítik a csoportnak. A termelői csoportok és termelői szervezet működési rendjét szabályozó előírások és azok betartása szorosan összefüggnek a közös agrárpolitikával és a hozzá kapcsolódó támogatási célok és eljárási rend elvárásaival.

\section{A gazdasági integráció együttmüködési szerződésen alapuló lehetőségei}

Az előző pontban említett termelői szervezetként illetőleg csoportként elismert szervezeteken belül kötelezően megjelenik a szerződéses kapcsolat követelménye a tag és az integrátori szervezet között a gazdasági tevékenység biztosítása érdekében. A szervezeten belüli integrációs együttmúködési megállapodástól azonban meg kell különböztetnünk az önálló jogalanyként mezőgazdasági tevékenységet végző személyek kooperációs kapcsolatait, szerződéses viszonyait. Ezek a szerződésen alapuló kapcsolatok változatosak lehetnek. Ilyen például a mezőgazdasági tevékenységet végzők között létrejött szerződés, vagy más jellegű az integrátor és mezőgazdasági tevékenységet végző személy között kialakított szerződéses rend, ahol az integrátor szolgáltatás nyújt a külső (nem tagja) integrált személynek. Az integrált szerződéses kapcsolat megkülönböztethető aszerint is, hogy az integráció milyen fokon, nagyságrendben (szerződött árbevétel volumen stb.), kiterjedéssel (integrált személyek száma stb.) valósul meg, amely szerint helyi, regionális és országos kapcsolati formákról beszélhetünk. A szerződéses kapcsolat termékekre, termékcsoportokra illetőleg termékpályára is kialakítható. 


\section{Csák Csilla \\ Integrált mezőgazdasági termelésszervezés \\ illetve az azt végző szervezetek}

Agrár- és Környezetjog

2018. 25. szám

A szerződéses jogviszony jogi szabályozását a Ptk. teremti meg. A Ptk. tipizált speciális szerződéses formákat szabályoz a saját termelésű mezőgazdasági áru szolgáltatására kötött adásvételi szerződés, ${ }^{10}$ valamint a vevő közremúködésével előállított mezőgazdasági áru szolgáltatására kötött adásvételi szerződés ${ }^{11}$ keretei között. A Nemzeti Agrárgazdasági Kamara kidolgozott egy javaslatot, mely a termékpálya szerinti integrált termelésszervezés szerződéses konstrukciójának kialakítására irányult. Az integrációs szerződést a javaslat sui generis szerződésként szabályozná, amelynek háttér jogszabálya a Ptk., a vevő közremúködésével előállított mezőgazdasági áru szolgáltatására kötött adásvételi szerződés szabályai illetőleg ötvözi a termelői szervezetekre vonatkozó szerződéses szabályokat. A szerződéses alanyai tekintetében ebben az integrációs konstrukcióban is lényeges feltétel az integráló szervezet állami elismerése illetőleg regisztrációjának a kérdése. A szolgáltatások és a gazdasági kapcsolatok elemein túl a modellhez kapcsolódó kedvezmények, előnyök lényegesek és előremutatóak: (a) a termelésszervező (integrátor) által az integrált vállalkozás számára a termelésszervezési (integrációs) szerződés alapján megtermelt termény, termék, termeléséhez, betakarításához, állat tartásához, valamint az ezek szállításához, feldolgozásához általa nyújtott gépi szolgáltatást az engedélyezés szempontjából az integrátor által saját maga által termelt termény, termék, termeléséhez, előállításához, állat tartásához végzett tevékenységnek kell tekinteni; (b) az integrátor által az integrált vállalkozás számára integrációs szerződés alapján elő́llított termék, termény, tenyésztett, tartott állat az integrátor által üzemeltetett fuvareszközzel történő szállítása, a termelésszervező (integrátor) saját maga által elóállított termék, termény, tenyésztett, tartott állat szállításának minősül; (c) a regionális-, illetve országos termelésszervezést (integrációt) megvalósító az általa integrált vállalkozás számára meghatározott pénzügyi szolgáltatásokat nyújthat, MNB engedély nélkül; (d) az országos termelésszervezést (integrációt) megvalósító vállalkozás által megvalósítandó legalább egymilliárd forint összeget meghaladó egyes beruházások nemzetgazdasági szempontból kiemelt

10 6:232. \[Saját termelésú mezógazdasági áru szolgáltatására kötött adásvételi szerzódés]

(1) Ha az eladó az adásvételi szerződésben maga termelte mezőgazdasági termény, termék, saját nevelésủ vagy hizlalású állat későbbi időpontban történő szolgáltatására vállal kötelezettséget, jogosult a szerződésben kikötött mennyiségnél tíz százalékkal kevesebbet teljesíteni.

(2) Az (1) bekezdés szerinti szerződést az eladó jogosult a kikötött teljesítési idő előtt is teljesíteni, feltéve, hogy a vevőt a teljesítés megkezdéséről az átvételhez szükséges felkészülési idő biztosításával előzetesen értesíti.

11 6:233. S [A vevö közremüködésével elöállitott mezógazdasági áru szolgáltatására kötött adásvételi szerzódés]

Ha az eladó az adásvételi szerződésben maga termelte mezőgazdasági termény, termék, saját nevelésű vagy hizlalású állat későbbi időpontban történő szolgáltatására vállal kötelezettséget, és a felek megállapodnak abban, hogy a vevő a teljesítést elősegítő szolgáltatást nyújt, továbbá ehhez kapcsolódó tájékoztatást ad az eladónak, akkor az eladó köteles ezt a szolgáltatást a tájékoztatásnak megfelelően igénybe venni. Az eladó a vevő teljesítést elősegítő szolgáltatásainak szerződés szerinti ellenértékét akkor is köteles megfizetni, és a vevő által folyósított termelési előlegnek a vételárral nem fedezett részét akkor is köteles visszafizetni, ha erre a termelés eredménye nem biztosít fedezetet. 


\section{Csák Csilla \\ Integrált mezőgazdasági termelésszervezés \\ illetve az azt végző szervezetek}

Agrár- és Környezetjog

2018. 25. szám

jelentőségű beruházásnak minősülnek; (e) a termelésszervező (integrátor) által a termelésszervezési (integrációs) szerződés keretében az áru a szerződéses szolgáltatás keretében történő értékesítése nem minősül nagykereskedelmi tevékenységnek; (f) Az adózás előtti eredmény legyen csökkenthető az elismert termelésszervező (integrátor) által a termelésszervezési (integrációs) szerződés keretében felvásárolt termék nettó árbevétele három százalékának megfelelő összegben képzett, és elkülönítetten kezelt kockázati alap helyezett összeggel, amely a termelésszervezési (integrációs) szolgáltatás teljesítésével összefüggő piaci kockázatok átvállalása miatti, valamint kutatási-, fejlesztési célú kifizetésekre felhasználható.

A kedvezmények jelentős része az adózási, pénzügyi teher csökkentési lehetőséget vetítenek előre javítva a működési környezet feltételrendszerét. Nagyon izgalmas kérdés ugyanakkor az integrátor pénzügyi szolgáltató funkciójának elismerése, legalizálása. A mezőgazdasági tevékenységet végző személyek számára az egyik és talán legfontosabb tényező az eszközellátottság és a pénzügyi stabilitás kérdése. Ennek megoldásában segíthet a javaslatban megfogalmazott szolgáltatási forma, amely eszközellátottság, pénzügyi szolgáltatások és az értékesítés oldaláról igény szerint javíthatja múködési feltételeiket. Ha a történeti előzményeket feleleveníthetjük, akkor a raiffeiseni pénzügyi szövetkezeti modell (XIX. sz. második fele) vállalta fel ezeket a feladatokat a német falusi lakosság irányában. Az alaptevékenységben a raiffeisen típusú hitelszövetkezetek túlmutattak a betétgyűjtésen, hitelnyújtáson, ugyanis a falu életének meghatározóivá váltak, azáltal, hogy a termelést segítették elő. Ez a cél határozta meg eszközeiket, amelyen belül jelentkezett a hitelezési tevékenység, de ide sorolható a beszerzés, értékesítés szervezése és egyéb közösségi szolgáltatások nyújtása is. ${ }^{12}$

\section{3. Érdekintegráció a mezőgazdaság keretei között}

A fenntartható fejlődés gondolata vagy a multifunkcionális mezőgazdaság modelljének megfogalmazása, de az uniós politikák külső és belső integrációjának a kérdése azt mutatják, hogy a célok megvalósításának tartalmi elemei sok esetben összetett kapcsolatrendszert mutatnak a kooperációs szintek és fajták között. Az viszont közös bennük, hogy az egyes tevékenységi területeken, meghatározott erőforrásokat mozgósítanak és kapcsolnak össze.

A mezőgazdasági tevékenységen alapuló foglalkoztatás új formái jelennek meg, mint pl. a szociális farm modell. A szociális farm modellben a társadalmi és a gazdasági kooperáció különböző szintű formái jelennek meg. A kölcsönhatás, együttmúködés, kooperáció irányai: (a) társadalmi felelősségvállalás, közös felelősség; (b) fenntartható mezőgazdaság; (c) környezettudatosság; (d) személyiségfejlesztés (készség- és képességfejlesztés); (e) ismeretátadás; (f) gazdasági előnyök (termelés, feldolgozás, értékesítés, felhasználás, jövedelem/bevétel).

A szociális farm a szociális szolidaritás elveinek megfelelően, a társadalmi és környezeti szemléletformálás érdekében múködő kooperatív gazdálkodási forma, amely mezőgazdasági termelő, feldolgozó, szolgáltató tevékenységet végez hátrányos helyzetű személyek bevonásával; illetőleg mezőgazdasághoz kapcsolódó szemléletformáló

12 Bátori Lóránt: A Raiffeisen-i szövetkezeti mozgalomról, Szövetkezés, 1997/1-2, 129-139. 
kiegészítő tevékenység végez a társadalom szélesebb köre számára. Az agrárgazdasági tevékenységet végző személyi kör tekintetében meghatározó a mezőgazdasági tevékenységből eredő árbevétel léte. Ebbe a csoportba kis,- közép,- és nagyüzemek tartoznak. A mezőgazdasági tevékenység végzésénél nincs formakényszer, azaz bármilyen szervezetei formában végezhető (gazdasági társasági formában, szövetkezeti formában, egyéni vállalkozói formában, őstermelőként, családi gazdasági formában stb.) A támogatási és adórendszer nagymértékben meghatározója a formaválasztásnak. A mezőgazdasági tevékenység nagyon szorosan kötődik mezőgazdasági földek használatához. Azt azonban meg kell jegyeznünk, hogy a mezőgazdasági földekre irányuló földhasználati és tulajdonlási jogosultsága csak meghatározott személyi körnek van a jogszabályi rendelkezések alapján. Ezt a korlátozó feltételt nem hagyhatjuk figyelmen kívül.

A Közös Agrárpolitikának az elmúlt évtizedek és a jelenkori kihívásaira tekintettel választ kellett adnia a fenntarthatóságra és előtérbe került a mezőgazdaság többfunkciós felfogása, a közjavak és a gazdaságok diverzifikálásának - többek között a vidéki életminőség javításának - a kérdése. Ez a kérdés és az az erre adandó válasz mindenképpen felveti a mezőgazdasági (alap)tevékenységnek illetőleg a kiegészítő tevékenységnek, valamint az azon kívüli tevékenységnek a bővítését, a gazdaságon belüli (on-farm) és a gazdaságon kívüli (off-farm) vonatkozásban egyaránt. Ez a folyamat a - specializációval ellentétben - a diverzifikáción keresztül elvezet bennünket a multifunkcionális megközelítéshez.

\section{Záró gondolatok}

A mezőgazdasági termelésszervezéssel kapcsolatos konstrukciók és jogi szabályozás fellelhető a korábbi időszak jogalkotásában és jelenleg hatályos szabályozásban is találunk erre utaló és kialakított jogintézményeket. Ennek lehetnek szorosabb és lazább kapcsolati formái abban az értelemben, hogy az integrativitás szerződéses kapcsolatra helyezésével nem szükséges a termelésszervezés lánc résztvevőinek a (cégjogi értelemben vett) szervezeti egység megteremtése, azaz tevékenységközpontú a szabályozás tartalma. Az azonban meghatározó, hogy közjogi és magánjogi értelemben vett előírások halmazát tekintve a szabályozás egy része csak diszpozitív, döntően a kógens szabályozási metodika érvényesül, ha az integrátori státuszról beszélünk. Lényeges kérdés az integrált modell elemeinek összeillesztése a különböző integrátori konstellációk szerepének tisztázása és egymáshoz való kapcsolódási pontjaik meghatározása. Mindemellett figyelemmel kell lenni arra is, hogy az integrált termelésszervezéssel kapcsolatos jogi szabályozás kialakítására az Alaptörvény is felhatalmazást tartalmaz. 